\title{
APPLICABILITY OF SUSTAINABLE CONSTRUCTION IN NIGERIA INFRASTRUCTURE PROJECTS- EMPIRICAL STUDY OF THE SIX GEOPOLITICAL ZONES
}

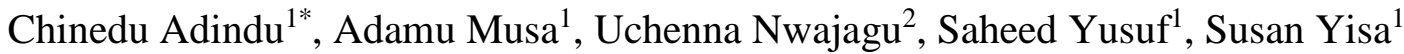 \\ ${ }^{1}$ Department of Project Management Technology, Federal University of Technology Minna, Nigeria \\ ${ }^{2}$ Centre for Environmental Management and Control, University of Nigeria, Nsukka, Nigeria
}

(Received: September 2020 / Revised: October 2020 / Accepted: November 2020)

\begin{abstract}
Despite the socio-economic importance of the Built Environment (BE) industry; its resources and products regrettably impact the host environment negatively, necessitating a departure from traditional to Sustainable Construction (SC) methods. Lack of SC awareness has been identified by several researchers as a major impediment to its adoption in Nigeria. This study, therefore, assessed the level of SC awareness, examined the sources of SC knowledge, and determined ways of improving SC applicability in Nigeria. The descriptive survey research methodology was used and a structured questionnaire administered purposively to $171 \mathrm{BE}$ professionals, with 133 valid responses, hence a $78 \%$ success rate. The results of the study showed that all the states in the six geo-political zones fell below the geopolitical zone mean awareness index (GZMAi) value of 0.700; a poor contribution of current academic curriculum, and poor site experience arising from paucity of SC knowledge on projects, as hindrances to its applicability. The study concludes that the characteristic low knowledge level of SC amongst BE professionals are institutionally based, and therefore, recommends adoption of global sustainability standards, increased sensitization of SC techniques via seminars and training workshops, the inclusion of SC in tertiary education curriculum, and in the certification programmes of BE professional institutions, amongst others.
\end{abstract}

Keywords: Applicability; Built Environment Industry; Nigeria; Sustainable Construction

\section{INTRODUCTION}

Construction for all purposes, real estate or otherwise is necessary for people to live, work, and satisfy their social and other needs, thus making it impossible for nations' economies to advance without its products (Medineckiene et al., 2010). The global construction investment was estimated to be around $\$ 17,140$ billion as of 2017 and is expected to grow to US $\$ 24,334.9$ billion by 2021 . The recent rise in global construction activities is attributable to the growing economy of emerging countries, increasing population, rising public-private partnerships in infrastructure development, and increasing government investment in large-scale infrastructure projects. In particular, construction investment in Africa, Asia Pacific, and the Middle East are projected to rise to US\$12.9 trillion by 2022 (Report Linker, 2019).

\footnotetext{
*Corresponding author's email: chinedu.adindu@futminna.edu.ng, Tel. +234 8034909898
} DOI: https://doi.org/10.32783/csid-jid.v3i2.161 
According to Tiwari et al. (2016) construction projects impact greatly on the environment with the majority being polluted, waste disposal, resource use, soil erosion, and material wastage, habitat destruction, desertification, and many others. Public Technology Inc. (2006) declared that construction projects contributed one-sixth of the world's freshwater, one-quarter of the wood harvest. While two-fifth of its materials and energy use have a significant impact on the environment, United Nations Environment Programme (2002) forecasts that between now and 2032 over $70 \%$ of the land surface will be ravaged with waste arising from increased construction and urbanization and its destructive consequences on natural resource and wildlife habitats. Despite the unprecedented socio-economic importance of the construction industry; regrettably, its resources and products impact the host environment negatively and significantly (Akadiri et al., 2012). Key among the specific impacts of construction include - public impacts, natural resource impacts, and ecosystem impacts (Zolfagharian et al., 2012). Tiwari et al. (2016), states that construction projects impact greatly on the environment with the majority being pollution, waste disposal, resource use, soil erosion, and material wastage, habitat destruction, desertification, and many others. Studies by the Inter-Governmental Panel on Climate Change (2007) forecasted the following as likely consequences should the Africa continent fail to take environmentally sustainable actions timely;

1. decrease in rainfall in the already arid regions of Eastern and Southern Africa

2. increase in drought and desertification in North Central Africa

3. severe water scarcity by 2025 in the West African countries of Benin Republic, Burkina Faso, Ghana, Mauritania, Niger, and Nigeria.

Governments of nations constitute major investors of Built Environment infrastructures the world over. They also, through their educational institutions, professional bodies, and relevant ministries, departments, and agencies (MDAs) provide enabling laws and statutes that regulate activities of various sectors of a national economy. Several studies have been made for the adoption of sustainable construction in Nigeria and the African continent. It attempts as a deliberate effort to stem the growing environmental challenges and impact of traditional methods of construction project delivery on the natural environment and the imperatives to align construction processes in the region with global practices (Allu \& Ebohon, John, 2014; Bond, 2011; Conejos et al., 2013; Eromobor \& Das, 2013). Arising therefrom, the applicability of sustainable construction in Nigeria, the African region, and other developing economies have witnessed several efforts of scholars and industry stakeholders in a bid to identify the challenges.

\subsection{Problem of Study, Research Gap and Justification of Study}

Studies by some researcher cover the lack of awareness of Sustainable construction by built environment industry stakeholders and pubic investors as a major impediment to its application in Nigeria, among others (Abisuga, A O; Oyekanmi, 2014; Aghimien et al., 2018; Dalibi et al., 2017; Nduka \& Ogunsanmi, 2015; Tunji-Olayeni et al., 2018). Several other kinds of research related to the application of sustainable construction in Nigeria focused severally on barriers/ challenges confronting it from several perspectives (Aghimien et al., 2018, 2019; Ametepey et al., 2015; Davies et al., 2017; Djokoto et al., 2014; Yusuf et al., 2019). Observedly, amongst the long list of challenges to SC adoption, lack of awareness on sustainable construction method is the most common. Studies by Alsanad (2015) also showed that 'lack of awareness' ranked highest amongst ten (10) barriers of sustainable construction in Kuwait with a mean value of 4.24. AlSanad's study also revealed that only $27.60 \%$ of the respondents had between 'good-excellent' knowledge of SC. Thus, the problems of lack of awareness and low knowledge of SC have assumed an international dimension and have become state-of-the-art in sustainable construction research. One of the issues surrounding the lack of SC awareness is the lack of historical data and 
the absence of pioneer projects for construction professionals to understudy (Aghimien et al., 2019).

This is expected and logical as one cannot adopt what he does not know. A common African saying goes thus- 'You cannot give what you do not have'. Arising therefrom, a study gap exists in the critical area of assessing the level of sustainable construction awareness, examining the available sources of SC knowledge, and determining ways of improving SC applicability amongst BE professionals in Nigeria. The study would also provide the much-needed database on low awareness, sources of knowledge, and ways of improving SC applicability by BE professionals in the nations' six geo-political zones.

\subsection{Research Objectives}

1. To assess the level of sustainable construction awareness amongst built environment professionals in Nigeria

2. To examine the sources of sustainable construction knowledge amongst built environment professionals in Nigeria

3. To determine the ways of improving sustainable construction applicability amongst built environment professionals in Nigeria

\section{SUSTAINABLE CONSTRUCTION}

Characteristic of all emerging fields, wholesome knowledge, and competence is scarce on SC with mixed and often divergent views on the phenomenon. Currently, there exist several thoughts, ideas, and terminologies in a bid to illuminate the concept of sustainable construction. Being sustainable in construction means considering of environmental, economic, and social impacts of operations considering the huge impact it has on society, environment, and economy (Aghimien et al., 2019; Agyekum-Mensah et al., 2012; Xia et al., 2016). Kibert (2016) states that sustainable construction involves reducing resource consumption, reusing resources, protecting nature, eliminating toxins, and emphasizing quality. Sustainable construction aims at production waste minimization, minimization of energy consumption, preservation and enhancement of water resources, and respect to people and environment (Atombo et al., 2015) views sustainable construction as a system that involves resource-efficient materials and methods that takes cognizance of health and well-being of the building's occupants, and future generations.

There has been a renewed call for the adoption of sustainable construction (Conejos et al., 2013; Eromobor \& Das, 2013). Butt et al. (2006) aver that construction industry activities should incorporate sustainability principles. Adebayo (2015) observed that sustainable construction failed to receive commensurate attention by industry stakeholders in Africa, despite the fact that construction practice in Africa is modeled after the experience of her colonists in developed economies (Taylor \& Norval, 1994). Adebayo (2015) stated that for sustainable construction to be applicable in the African continent, due consideration must be given to its political, economic, social, and developmental peculiarities. The benefits and essence of sustainability cannot be overemphasized in the construction industry. Yusuf et al. (2019) study posited that the construction industry's method of work delivery and resource usage adversely impact the environment and there exists a high level of awareness of the negative impacts of construction activities in Nigeria. WS Atkins Consultants (2001) states that concerted action is required by built environment personnel with duties of design, consulting, and construction services in order to implement sustainable construction. Akadiri et al. (2012) stated that professionals in the building industry are determined to improve on the mode of operations in order to correct the negative impact construction activities have on the environment and went further to recommend the incorporation of sustainability objectives at the design development stage of projects. Aghimien \& Awodele (2018) opines that construction professionals should endeavor to deliver 
projects that promote preservation of the natural environment, enhancement of social well-being of the occupants, and profitable revenue returns for the investors. Ugwu et al. (2006) state that current sustainability efforts lay greater emphasis on global level multisectoral strategies instead of project-level specific considerations and decision support. Akadiri et al. (2012) averred that sustainability objectives and decisions in the construction industry can only be achieved and made at the project-level through comprehensive measures.

Attia \& De Herde (2011) declared that decisions on building production processes have long term effects on the environment. Amos et al. (2018) extensive study on the benefits of sustainable construction, revealed an overwhelming fifty-six (56) benefits to the construction industry. Notable among the numerous benefits of sustainable construction include- cost reduction, waste minimization, increased health benefits, environmental sustainability, and reduced pollution runoff into waterways (Dahiru et al., 2014). Dahiru et al. (2014) study further identified reduced capital and operation cost, health and productivity gains, reduced liability risk, and preservation of depleting natural resources as additional benefits of sustainable construction practice in Nigeria. Miranda \& Marulanda (2015) posited that the multiplying effect of sustainable construction is enormous on the economy, especially the reduction of irrational consumption of natural resources.

Williams \& Dair (2007) study identified cost implications of sustainable construction, stakeholders' lack of consideration of sustainability, inexperience in sustainable designs, clients' reluctance, a lack of the right information, non-availability of sustainable construction materials, and lack of capacity for execution of sustainable construction projects. Findings from other studies (Aghimien et al., 2018; Akinshipe et al., 2019; Dahiru et al., 2014; Ezeagu et al., 2015) also support that lack of knowledge, interest, and expertise from project stakeholders pose as greatest challenges in the bid to adopt sustainable construction. According to Miranda \& Marulanda (2015), the lack of government support for the mobilization of resources to support research, technological changes, and feasibility studies for the production and marketing of new materials and technologies is a key challenge. Furthermore, the study highlights other barriers such as poverty and low urban investment, lack of knowledge on risks and effects of unsustainable construction and urbanization practices, and lack of efficiency in managing growing demands for public services.

\section{METHODOLOGY}

The study is descriptive survey research, while the research design involved a structured questionnaire administered to selected construction industry professionals with at least a post National Youth Service Corps practice experience. Both primary and secondary data were used in the research. The questionnaire had two compartments, and aside from information on respondents' bio-data, also sought responses on critical issues relating to sustainable construction to assess respondents' level of knowledge and perception of the subject matter. The population of the study comprised several BE industry personnel in the employ of government ministries, departments, and agencies (MDAs), construction companies, consultancy firms, client organisations, construction labour organisations, building materials manufacturers and dealers, and many others.

The aforementioned study respondents worked on projects located in the Federal Capital Territory, Abuja, and other 18 states of the federation, with three states chosen from each of the nation's six geo-political zones, viz: North-East (Bauchi-BA, Adamawa-AD, Taraba-TR), NorthWest (Kaduna-KD, Kano-KN, Katsina-KT), North Central(Niger-NG, Benue-BN, Kwara-KW), South-East (Enugu-EN, Imo-IM, Ebonyi-EB), South-West (Lagos-LA, Ogun-OG, Edo-ED), and South-South ( Akwa Ibom-AI, Bayelsa-BY, Rivers-RV). Three sizes of firms namely-small, 
medium, and large were identified and used as a basis for categorizing the professionals in each of the 19 states studied (inclusive of the FCT, Abuja). As such, 9 questionnaires were issued to each state, making a total of 171 questionnaires. A total of 147 questionnaires were returned out of which 133 were valid. The 14 returned questionnaires were discarded for reasons ranging from partial completion to wrong entries. The 133 valid responses represent a $78 \%$ success rate. This return rate was considered adequate and sufficiently representative of the sample population for purposes of data presentation, analysis, conclusion, and recommendation on the study. This assertion is based on Moser (2017) recommendation that response rates lower than $30-40 \%$ are subject to bias and of little value.

Table 1. Descriptive statistics of demographic features of the BE industry respondents

\begin{tabular}{|c|c|c|c|}
\hline & & Frequency & Percentage \\
\hline \multirow{3}{*}{ Gender } & Male & 90 & 67.67 \\
\hline & Female & 43 & 32.33 \\
\hline & TOTAL & 133 & 100.00 \\
\hline \multirow[t]{6}{*}{ Age } & $20-24$ & 13 & 9.77 \\
\hline & $25-29$ & 27 & 20.30 \\
\hline & $30-34$ & 31 & 23.31 \\
\hline & $35-39$ & 35 & 26.32 \\
\hline & 40 - above & 27 & 20.30 \\
\hline & TOTAL & 133 & 100.00 \\
\hline \multirow[t]{7}{*}{ Level of Education } & ND/OND & 16 & 12.03 \\
\hline & HND/BSc/BEng/BTech & 72 & 54.14 \\
\hline & MSc/MEng/MTech & 23 & 17.29 \\
\hline & PhD & 8 & 6.02 \\
\hline & Trade certificate & 10 & 7.52 \\
\hline & Others & 4 & 3.00 \\
\hline & TOTAL & 133 & 100.00 \\
\hline \multirow[t]{11}{*}{ Discipline } & Engineer & 22 & 16.54 \\
\hline & Quantity Surveyor & 16 & 12.03 \\
\hline & Architect & 19 & 14.29 \\
\hline & Project Manager & 9 & 6.77 \\
\hline & Builder & 18 & 13.53 \\
\hline & $\begin{array}{l}\text { Environmental } \\
\text { Manager }\end{array}$ & 13 & 9.77 \\
\hline & Land surveyor & 11 & 8.27 \\
\hline & Town planner & 8 & 6.01 \\
\hline & Estate Surveyor & 12 & 9.03 \\
\hline & Other BE professionals & 5 & 3.76 \\
\hline & TOTAL & 133 & 100.00 \\
\hline \multirow{7}{*}{$\begin{array}{l}\text { Professional } \\
\text { Experience }\end{array}$} & $1-5$ & 21 & 15.79 \\
\hline & $5-10$ & 15 & 11.28 \\
\hline & $10-15$ & 23 & 17.29 \\
\hline & $15-20$ & 26 & 19.55 \\
\hline & $20-25$ & 28 & 21.05 \\
\hline & Over 25 years & 20 & 15.04 \\
\hline & TOTAL & 133 & 100.00 \\
\hline
\end{tabular}

A Likert 5-point scale was used, and respondents were required to indicate their extent of agreement to identified variable factors under the measure, from 'High to Low' viz- To a Great Extent (TGE), To a Considerable Extent (TCE), To a Moderate Extent (TME), To a Low Extent 
(TLE), and To No Extent (TNE). To ensure only high agreement to variable factors under a measure in the analysis of objective -3 (ways of improving sustainable construction applicability amongst built environment professionals in Nigeria), a modification was made to the 5-point Likert scale to take cognisance of only the mid-scale of TME and above. Thus, only TME, TCE, and TGE were used in the final analysis for the computation of their total respondents per variable factor, agreement index, and the rank order of agreement.

A combination of descriptive and inferential statistics was employed in the study and the analysis was effected with the aid of statistical package for social sciences (SPSS), version 10.0. The methodology used in this study followed the path established by scholars like Aghimien et al. (2019) in which Cronbach's alpha test was conducted to determine the reliability of the questionnaire, while the Shapiro-Wilk normality test was conducted to determine the normality of the data gathered. For this study, the Cronbach Alpha test conducted to ascertain the reliability of the research instruments yielded 0.946; this high coefficient attests to the reliability and consistency of the survey instrument used. Also, the Shapiro-Wilk test conducted on 133 valid samples (less than 2000), showed 0.001, and as such, satisfied the criteria for sample size normality (Ghasemi \& Zahediasl, 2012). Furthermore, study analysis was carried out using the average relative index (ARI) techniques (Olanrewaju \& Anahve, 2015).

$A R I=\frac{\sum_{i=0}^{5} a i x i}{5 \sum_{i=0}^{5} x i}(0 \leq \mathrm{ARI} \leq 1)$

This was particularly used to establish the State Awareness indices (SAWi), the associated GeoZones Mean Awareness indices (GZMAi), Source of Knowledge indices (Ski), and the States Agreement indices (SAGi). Whereas $a_{i}$, is the index of a group; a constant expressing the weight given to the group; $\mathrm{xi}$ is the frequency of response; $\mathrm{i}=1,2,3,4,5, \mathrm{x}_{1}, \mathrm{x}_{2}, \mathrm{x}_{3}, \mathrm{x}_{4}, \mathrm{x}_{5}$, are the frequencies of the response corresponding to $\mathrm{a}_{1}=1, \mathrm{a}_{2}=2, \mathrm{a}_{3}=3, \mathrm{a}_{4}=4, \mathrm{a}_{5}=5$, respectively. As such, for purposes of interpretation, 0 (zero) is the lowest possible score, whereas, 1 (one) is the highest possible score.

\section{RESULTS AND DISCUSSION}

Table 1 reports on the descriptive statistics/demographic features of the BE industry respondents. The results showed that of the 171 questionnaires issued out, 133no, representing $77.78 \%$ returned successfully. 90 respondents representing $67.67 \%$ were male, while 43 representing $32.33 \%$ were female. $69.93 \%$ of the respondents were over 30 years of age, while $77.45 \%$ had educational qualifications ranging from HND to Ph.D. Furthermore, over $96.24 \%$ of the respondents were built environment professionals, and $72.93 \%$ had industry experience spanning over 10 years. It is evident that based on the relatively high education and long industry experience of the respondents, data obtained therefrom could be used as a basis for arriving at findings, conclusion, and recommendation on the study.

\subsection{Objective 1}

Table 2 reports on the level of Sustainable Construction awareness among built environment industry professionals in Nigeria and showed that the Federal Capital Territory, Abuja had the highest state awareness index (SAWi) of 0.68 among all the 19 states covered by the study. The zonal results showed that Edo state of the South west geo-political zone was next with an SAWi of 0.66, followed closely by Lagos state -with a SAWi of 0.65 and also of the South-west zone. The result further revealed that Abia state (South-East geo-zone); Akwa Ibom state, Bayelsa state both of the South-south geo-zone and Kaduna state (North west geo-zone) all had a tie with a 
SAWi of 0.63 each. Enugu state (South-east GZ) and Rivers state (South-South GZ) followed closely with SAWi of 0.60 each. Ogun state (South-West GZ, SAWi:0.57), and Kwara state (North Central GZ, SAWi:0.53) followed accordingly.

Table 2. Descriptive statistics of 'level of sustainable construction awareness among built environment industry professionals in Nigeria'

\begin{tabular}{|c|c|c|c|c|c|c|c|c|c|c|c|}
\hline S/No & $\begin{array}{l}\text { Geo- } \\
\text { zone }\end{array}$ & $\begin{array}{l}\text { States } \\
\text { studied }\end{array}$ & $\begin{array}{c}\text { No of } \\
\text { Respondents }\end{array}$ & $\begin{array}{c}\text { TGE } \\
5\end{array}$ & $\begin{array}{c}\text { TCE } \\
4\end{array}$ & $\begin{array}{c}\text { TME } \\
3\end{array}$ & $\begin{array}{c}\text { TLE } \\
2\end{array}$ & $\begin{array}{c}\text { TNE } \\
1\end{array}$ & SAWi & GZMAi & ROGZMAi \\
\hline 1 & FCT (9) & Abuja & 9 & 2 & 3 & 2 & 1 & 1 & 0.68 & & \\
\hline \multirow[t]{3}{*}{2} & North & Kwara & 8 & - & 2 & 2 & 3 & 1 & 0.53 & & \\
\hline & \multirow{2}{*}{$\begin{array}{c}\text { Central } \\
\text { (22) }\end{array}$} & Niger & 8 & - & 2 & 2 & 1 & 1 & 0.43 & 0.510 & 5 th \\
\hline & & Benue & 6 & 1 & 1 & 1 & 2 & 1 & 0.57 & & \\
\hline \multirow[t]{3}{*}{3} & \multirow{3}{*}{$\begin{array}{c}\text { North } \\
\text { East } \\
(18)\end{array}$} & Bauchi & 7 & 1 & 1 & 2 & 3 & - & 0.60 & & \\
\hline & & Adamawa & 6 & - & - & 2 & 2 & 2 & 0.40 & 0.507 & 6th \\
\hline & & Taraba & 5 & - & 1 & 1 & 3 & - & 0.52 & & \\
\hline \multirow[t]{3}{*}{4} & \multirow{3}{*}{$\begin{array}{l}\text { North } \\
\text { West } \\
(18)\end{array}$} & Kano & 7 & - & 1 & 2 & 3 & 1 & 0.49 & & \\
\hline & & Katsina & 4 & - & - & 2 & 1 & 1 & 0.45 & 0.523 & 4 th \\
\hline & & Kaduna & 7 & 1 & 1 & 3 & 2 & - & 0.63 & & \\
\hline \multirow[t]{3}{*}{5} & \multirow{3}{*}{$\begin{array}{c}\text { South } \\
\text { East } \\
(22)\end{array}$} & Enugu & 8 & 1 & 2 & 2 & 2 & 1 & 0.60 & & \\
\hline & & Ebonyi & 7 & - & 1 & 2 & 2 & 2 & 0.46 & 0.563 & $3 \mathrm{rd}$ \\
\hline & & Abia & 7 & 1 & 2 & 2 & 1 & 1 & 0.63 & & \\
\hline \multirow[t]{3}{*}{6} & \multirow{3}{*}{$\begin{array}{l}\text { South } \\
\text { West } \\
(21)\end{array}$} & Lagos & 8 & 1 & 2 & 3 & 2 & - & 0.65 & & \\
\hline & & Ogun & 6 & - & 2 & 1 & 3 & - & 0.57 & 0.627 & $1 \mathrm{st}$ \\
\hline & & Edo & 7 & 2 & 1 & 2 & 1 & 1 & 0.66 & & \\
\hline \multirow[t]{5}{*}{7} & \multirow{3}{*}{$\begin{array}{c}\text { South } \\
\text { South } \\
(23)\end{array}$} & Bayelsa & 6 & 1 & 1 & 2 & 2 & - & 0.63 & & \\
\hline & & $\begin{array}{l}\text { Akwa- } \\
\text { Ibom }\end{array}$ & 8 & 1 & 2 & 2 & 3 & - & 0.63 & $0 . .620$ & 2 nd \\
\hline & & Rivers & 9 & 1 & 2 & 3 & 2 & 1 & 0.60 & & \\
\hline & TOTAL & 19 & 133 & 13 & 27 & 37 & 38 & 14 & & & \\
\hline & $\%$ & & 100 & 9.77 & 20.30 & 27.82 & 28.57 & 13.54 & & & \\
\hline
\end{tabular}

** State Awareness Index (SAWi); Geo-Zones Mean Awareness Index (GZMAi); Rank Order of Geo Zones Mean Awareness Index (ROGZMAi)

The computed geo-political zones mean awareness indices (GZMAi) reveals that South-West (SW) ranked 1st with 0.627 GZMAi; South-South (SS) 2nd, with 0.620 GZMAi; South-East (SE)3rd, with 0.563 GZMAi; North -West (NW)4th, with 0.523 GZMAi; North-Central (NC)5th, with 0.510 GZMAi; North East (NE)6th, with 0.507 GZMAi. The results of the empirical study showed that all the states studied fell below the minimum acceptable SAWi threshold of 0.700 . Consequently, none of Nigeria's six geo-political zones met GZMAi threshold of 0.700 and above, implying poor national awareness of sustainable construction practice, and hence little prospects of applicability in Nigeria. The study result avers with the previous studies that revealed 'lack of awareness' as a major challenge confronting the applicability of sustainable construction in Nigeria (Aghimien et al., 2018, 2019; Ametepey et al., 2015; Davies et al., 2017; Djokoto et al., 2014; Yusuf et al., 2019).

\subsection{Objective 2}

Table 3 sought to inquire on the sources of knowledge of SC among the BE professionals in the selected states of the nation's six geo-political zones. The results show that Workshops/Conferences ranked 1st as the most common source of acquiring Sustainable Construction knowledge with a Source of Knowledge Index (SKi) of 0.3384. This was closely followed by mentorship -2nd with SKi of 0.3083; online training - 3rd (SKi: 0.1579); Tertiary education curriculum ranked 4th (SKi: 0.1278); while site experience ranked 5th (SKi: 0.0752). The results of the study reveal the poor contribution of the academic curriculum in the training $\mathrm{BE}$ professionals for SC competences. This accounts for the low knowledge and low adoption of Sustainable construction principles and techniques. 
Table 3. Descriptive statistics of 'Identified Sources of Sustainable Construction Knowledge among Built Environment industry professionals in Nigeria'

\begin{tabular}{|c|c|c|c|c|c|c|c|c|}
\hline \multirow[t]{2}{*}{ S/No } & \multirow{2}{*}{$\begin{array}{l}\text { Geo- } \\
\text { zone }\end{array}$} & \multirow{2}{*}{$\begin{array}{c}\text { States } \\
\text { studied }\end{array}$} & \multirow{2}{*}{$\begin{array}{c}\text { No of } \\
\text { Respondents }\end{array}$} & \multirow[b]{2}{*}{$\begin{array}{c}\text { Site } \\
\text { experience }\end{array}$} & \multicolumn{4}{|c|}{ Identified Variable Factor } \\
\hline & & & & & $\begin{array}{l}\text { Online } \\
\text { training }\end{array}$ & $\begin{array}{l}\text { Workshops/ } \\
\text { Conferences }\end{array}$ & $\begin{array}{c}\text { Tertiary } \\
\text { education } \\
\text { curriculum }\end{array}$ & Mentorship \\
\hline 1 & FCT & Abuja & 9 & 2 & 1 & 3 & 1 & 2 \\
\hline \multirow[t]{3}{*}{2} & North & Kwara & 8 & 1 & 1 & 2 & 2 & 2 \\
\hline & Central & Niger & 8 & - & 2 & 2 & - & 4 \\
\hline & & Benue & 6 & - & 1 & 1 & 1 & 3 \\
\hline \multirow[t]{3}{*}{3} & North & Bauchi & 7 & 1 & 1 & 2 & 1 & 2 \\
\hline & East & Adamawa & 6 & 1 & 1 & 3 & - & 1 \\
\hline & & Taraba & 5 & - & 1 & 2 & 1 & 1 \\
\hline \multirow[t]{3}{*}{4} & North & Kano & 7 & - & 1 & 2 & 1 & 3 \\
\hline & West & Katsina & 4 & - & - & 2 & 1 & 1 \\
\hline & & Kaduna & 7 & - & 1 & 3 & 2 & 1 \\
\hline \multirow[t]{3}{*}{5} & South & Enugu & 8 & 1 & 1 & 3 & 1 & 2 \\
\hline & East & Abia & 7 & 1 & 1 & 2 & 2 & 2 \\
\hline & & Ebonyi & 7 & - & 2 & 2 & - & 3 \\
\hline \multirow[t]{3}{*}{6} & South & Lagos & 8 & - & 1 & 4 & 1 & 2 \\
\hline & West & Ogun & 6 & & 1 & 2 & 1 & 2 \\
\hline & & Edo & 7 & 1 & 1 & 2 & - & 3 \\
\hline \multirow[t]{6}{*}{7} & $\begin{array}{l}\text { South } \\
\text { South }\end{array}$ & $\begin{array}{l}\text { Akwa- } \\
\text { Ibom }\end{array}$ & 6 & - & 1 & 3 & - & 2 \\
\hline & & Bayelsa & 8 & 1 & 1 & 2 & 1 & 3 \\
\hline & & Rivers & 9 & 1 & 2 & 3 & 1 & 2 \\
\hline & & TAL & 133 & 10 & 21 & 45 & 17 & 41 \\
\hline & & $\mathrm{ki}$ & & 0.0752 & 0.1579 & 0.3384 & 0.1278 & 0.3083 \\
\hline & & $\mathrm{SKi}$ & & 5th & $3 \mathrm{rd}$ & $1 \mathrm{st}$ & 4th & 2 nd \\
\hline
\end{tabular}

**Source of Knowledge Index (Ski); Rank Order of Source of knowledge Index (ROSKi)

Knowledge from site experience ranked 5th, thus, asserting the research position of Aghimien et al., (2019) which stated 'lack of historical data and absence of pioneer projects for construction professionals' as a major hindrance of sustainable construction applicability in Nigeria. There is a lack of pioneer SC projects for BE professionals to build their site experience. The results of this study would expectedly address the current paucity of data by providing major empirical support on the dispersion of specific sources of sustainable construction knowledge among BE professionals in Nigeria.

\subsection{Objective 3}

Lack of SC awareness will impede the adoption of the system in the nations' infrastructure projects. Thus, there was a need to investigate the ways by which the current awareness level of $\mathrm{SC}$ can be improved upon. 


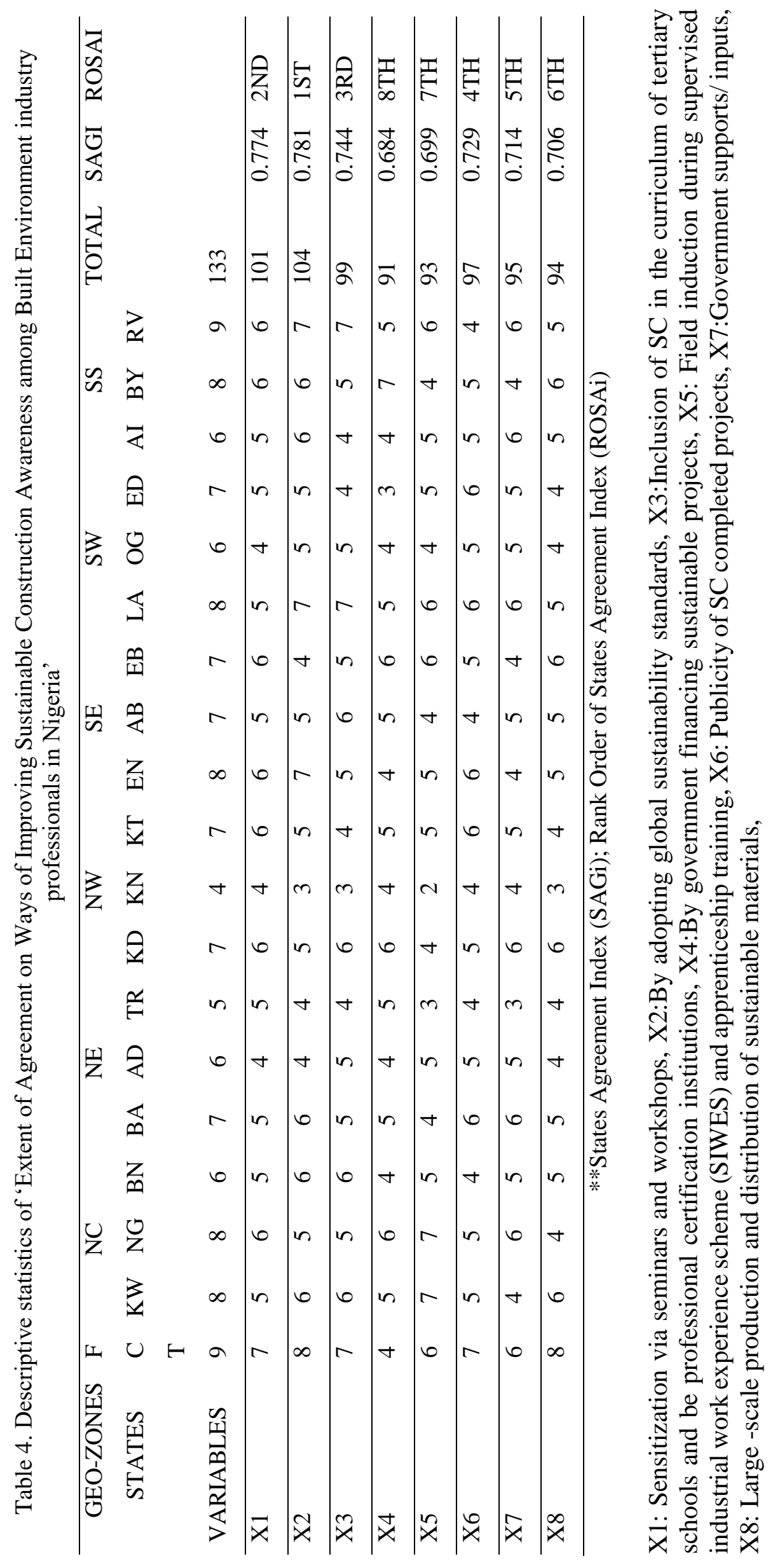


Results shown on Table 4 reveals that 'by following global sustainability standards ranked 1st with SAGi value of 0.781 . The alignment with global practices is supported by the researches of Bond, 2011; Conejos et al., 2013; Eromobor \& Das, 2013; and Allu \& Ebohon, 2014. Sensitization via seminars and workshops came 2 nd with SAGi value of 0.774 . The result further aligns with Yusuf et al. (2019), which stated the need for sustainability enlightenment among construction personnel and stakeholders. Inclusion of SC in secondary and tertiary education curriculum came 3rd with SAGi value of 0.744 .

The study result was also supported by an earlier study of Yusuf et al. (2019), which posited an entrenchment of SC principles, skills, and competency in built environment curriculum for both academic and professional certifications. Publicity of SC completed projects, and Government support/input ranked 4th and 5th and with SAGi values of 0.729 and 0.714 respectively. The results on the publicity of SC completed projects aligned with those of Aghimien et al. (2019) which declared 'lack of historical data and absence of pioneer projects for construction professionals' as a major hindrance of sustainable construction applicability in Nigeria. Study results on government support/ inputs is supported by Miranda \& Marulanda (2015) which stated that lack of government support was critical for mobilization of SC resources and to drive research, technological changes, and feasibility studies for the production/ marketing of new materials and technologies.

\section{CONCLUSION}

Nigeria has witnessed a slow transition from its traditional construction methods to contemporary sustainable construction. The study established that low awareness of SC and its poor emphasis by tertiary education curriculum constitute major challenges to its applicability in the $\mathrm{BE}$ industry. The study revealed that the current low awareness of sustainable construction and its improvement are institutionally based and recommend collaboration of the government, academic, professional institutions, and general BE industry stakeholders for policy enactments and decision support for improved awareness and increased knowledge of sustainable construction principles and techniques for wider application in Nigeria. The study recommends payment of particular attention to the adoption of global sustainability standards, increased sensitization of SC principles in seminars and training workshops by BE professional bodies. There is also a need for additional attention to comprehensive syllabus development on SC and structured teaching by tertiary institutions offering BE courses, practical field induction on SC techniques during students' industrial work experience schemes (SIWES), improved publicity of completed SC projects to serve as models for referrals and case studies, full governmental support of developmental policies on SC implementation on private and public infrastructure projects in Nigeria.

\section{REFERENCES}

Abisuga, A O; Oyekanmi, O. (2014). Organizational Factors Affecting the Usage of Sustainable Building Materials in the Nigerian Construction Industry. Journal of Emerging Trends in Economic and Management Science, 5(2), 113-119. http://0search.proquest.com.wam.leeds.ac.uk/docview/1531041290? accountid=14664

Adebayo, A. A. (2015). Sustainable Construction In Africa - Agenda 21 for Sustainable Construction in Developing Countries. Conference Proceedings of International Council for Research and Innovation in Building and Construction. https://www.irbnet.de/daten/iconda/CIB659.pdf

Aghimien, D. O., Adegbembo, T. F., Aghimien, E. I., \& Awodele, O. A. (2018). Challenges of Sustainable Construction: A Study of Educational Buildings in Nigeria. International Journal of Built Environment and Sustainability, 5(1). 
https://doi.org/10.11113/ijbes.v5.n1.244

Aghimien, D. O., Aigbavboa, C., Ngcobo, N., \& Thwala, W. D. (2019). Challenges of Sustainable Construction: A Study of Educational Buildings in Nigeria. 13th Built Environment Conference.

Agyekum-Mensah, G., Knight, A., \& Coffey, C. (2012). 4Es and 4 Poles model of sustainability: Redefining sustainability in the built environment. In Structural Survey (Vol. 30, Issue 5, pp. 426-442). https://doi.org/10.1108/02630801211288206

Akadiri, P. O., Chinyio, E. A., \& Olomolaiye, P. O. (2012). Design of a sustainable building: A conceptual framework for implementing sustainability in the building sector. Buildings, 2(2), 126-152. https://doi.org/10.3390/buildings2020126

Akinshipe, O., Oluleye, I. B., \& Aigbavboa, C. (2019). Adopting sustainable construction in Nigeria: Major constraints. IOP Conference Series: Materials Science and Engineering, 640, 012020. https://doi.org/10.1088/1757-899X/640/1/012020

Allu, E., \& Ebohon, John, O. (2014). Climate Change and Buildings in Nigeria: Lessons from a Field Survey. Academic Journal of Science, 3(2), 197-206.

Alsanad, S. (2015). Awareness, Drivers, Actions, and Barriers of Sustainable Construction in Kuwait. Procedia Engineering, 118, 969-983. https://doi.org/10.1016/j.proeng.2015.08.538

Ametepey, O., Aigbavboa, C., \& Ansah, K. (2015). Barriers to Successful Implementation of Sustainable Construction in the Ghanaian Construction Industry. Procedia Manufacturing, 3, 1682-1689. https://doi.org/10.1016/j.promfg.2015.07.988

Atombo, C., Cudjoe, J., Dzantor, K., \& Agbo, A. A. (2015). Integration of Sustainable Construction in Project Management: A Case Study in Ghana. International Journal of Construction Engineering and Management, 4(1), 13-25. http://journal.sapub.org/ijcem

Attia, S. G., \& De Herde, A. (2011). Early design simulation tools for net zero energy buildings: A comparison of ten tools. Proceedings of Building Simulation 2011: 12th Conference of International Building Performance Simulation Association, 94-101.

Bond, S. (2011). Barriers and drivers to green buildings in Australia and New Zealand. Journal of Property Investment and Finance, 29(4), 494-509. https://doi.org/10.1108/14635781111150367

Butt, T. E., Umeadi, B. B. N., \& Jones, K. G. (2006). Sustainable development and climate change induced obsolescence in the built environment. American Journal Of Physiology, $305,1-15$.

Conejos, S., Langston, C., \& Smith, J. (2013). AdaptSTAR model: A climate-friendly strategy to promote built environment sustainability. Habitat International, 37, 95-103. https://doi.org/10.1016/j.habitatint.2011.12.003

Dahiru, D., Dania, A. A., \& Adejoh, A. (2014). An investigation into the prospects of green building practice in Nigeria. Journal of Sustainable Development, 7(6), 158-167. https://doi.org/10.5539/jsd.v7n6p158

Dalibi, S. G., Feng, J. C., Shuangqin, L., Sadiq, A., Bello, B. S., \& Danja, I. I. (2017). Hindrances to Green Building Developments in Nigeria's Built Environment: "the Project Professionals", Perspectives"." IOP Conference Series: Earth and Environmental Science, 63(1), 012033. https://doi.org/10.1088/1755-1315/63/1/012033

Darko, A., Owusu, E., Chan, A., \& Antwi-Afari, M. (2018). Benefits of Green Building: A Literature Review. Urban Construction Management: The Role of ICT An Emerging Technologies In External Stakeholder Management, April, 1. www.rics.org/cobraconference

Davies, O. O. A., Davies, I. O. E., Davies, O O A and Davies, I. O. E., Davies, O. O. A., \& Davies, I. O. E. (2017). Barriers to Implementation of Sustainable Construction Techniques. MAYFEB Journal of Environmental Science, 2, 1-9.

Djokoto, S. D., Dadzie, J., \& Ohemeng-Ababio, E. (2014). Barriers to sustainable construction 
in the ghanaian construction industry: Consultants perspectives. Journal of Sustainable Development, 7(1), 134-143. https://doi.org/10.5539/jsd.v7n1p134

Eromobor, S., \& Das, D. (2013). Dynamic Modelling Approach for Designing Sustainable Green Buildings. In F. A. Emuze (Ed.), SB13 Southern Africa Conference. Central University of Technology, Free

State. http://site.cibworld.nl/dl/publications/Proceedings_SB13_South_Africa_Conference.pdf\#p age $=16$

Ezeagu, C. ., Udebunu, J. ., \& Obiorah, S. M. (2015). Destructive and Non-Destructive Assessment of Collapsed Structures in Onitsha, Anambra State, Nigeria. American Scientific Research Journal for Engineering, Technology, and Sciences, 12(8), 170-186.

Ghasemi, A., \& Zahediasl, S. (2012). Normality tests for statistical analysis: A guide for nonstatisticians. International Journal of Endocrinology and Metabolism, 10(2), 486-489. https://doi.org/10.5812/ijem.3505

Intergovernmental Panel on Climate Change. (2007). Climate Change 2007: The Physical Science Basis - Summary for Policymakers. https://previa.uclm.es/area/amf/antoine/energias/Ipcc_anotado.pdf

J. Kibert, C. (2016). Sustainable Construction: Green Building Design and Delivery (4th Editio). John Wiley and Sons, Inc. https://www.wiley.com/enid/Sustainable+Construction\%3A+Green+Building+Design+and+Delivery\%2C+4th+Editi on-p-9781119055174

Medineckiene, M., Turskis, Z., \& Zavadskas, E. K. (2010). Sustainable construction taking into account the building impact on the environment. Journal of Environmental Engineering and Landscape Management, 18(2), 118-127. https://doi.org/10.3846/jeelm.2010.14

Miranda, L., \& Marulanda, L. (2015). Sustainable Construction in Developing Countries: A Peruvian Perspective - Agenda 21 for Sustainable Construction in Developing Countries. https://www.irbnet.de/daten/iconda/CIB662.pdf

Moser, C. A. (2017). Survey Methods in Social Investigation. In Survey Methods in Social Investigation. Routledge. https://doi.org/10.4324/9781315241999

Nduka, D. O., \& Ogunsanmi, O. E. (2015). Stakeholders Perception of Factors Determining the Adoptability of Green Building Practices In Construction Projects In Nigeria. Journal of Environment and Earth Science, 5(2), 188-196. www.iiste.org

Olanrewaju, A., \& Anahve, P. J. (2015). Duties and Responsibilities of Quantity Surveyors in the Procurement of Building Services Engineering. Procedia Engineering, 123, 352-360. https://doi.org/10.1016/j.proeng.2015.10.046

Public Technology Inc. (2006). Sustainable Building, Technical manual: Green Building Design, Construction and Operation. https://pdhonline.com/courses/g240/Buiilding _ Systems_ and_IAQ-Sustainabledesignmanual.pdf

Report Linker. (2019). Global Construction Outlook to 2023 - Q4 2019 Update. https://www.reportlinker.com/p05751454/Global-Construction-Outlook-to-Q4Update.html

Taylor, R. G., \& Norval, G. H. M. (1994). Developing Appropriate Procurement Systems for Developing Communities. CIB W92 Symposium, CIB Publication. https://www.irbnet.de/daten/iconda/CIB12605.pdf

Tiwari, V. K., Verma, A., Kumar, A., \& Gupta, M. (2016). A review on Environmental Impact Assessment of Construction Projects. IOSR Journal of Environmental Science, 10(1), 2125. https://doi.org/10.9790/2402-10112125

Tunji-Olayeni, P. F., Mosaku, T. O., Oyeyipo, O. O., \& Afolabi, A. O. (2018). Sustainability strategies in the construction industry: Implications on Green Growth in Nigeria. IOP Conference Series: Earth and Environmental Science, 146(1). https://doi.org/10.1088/17551315/146/1/012004 
Ugwu, O. O., Kumaraswamy, M. M., Wong, A., \& Ng, S. T. (2006). Sustainability appraisal in infrastructure projects (SUSAIP): Part 1. Development of indicators and computational methods. Automation in Construction, 15(2), 239-251. https://doi.org/10.1016/j.autcon.2005.05.006

United Nations Environment Programme. (2002). Global Environment Outlook 3-Past, present and future perspectives.

W.S. Atkins consultants. (2001). Sustainable Construction: Company Indicators: C563 (CIRIA). Construction Industry Research and Information Association. https://www.amazon.com/Sustainable-Construction-Company-IndicatorsCIRIA/dp/0860175634

Williams, K., \& Dair, C. (2007). What is stopping sustainable building in England? Barriers experienced by stakeholders in delivering sustainable developments. Sustainable Development, 15(3), 135-147. https://doi.org/10.1002/sd.308

Xia, B., Rosly, N., Wu, P., Bridge, A., \& Pienaar, J. (2016). Improving sustainability literacy of future quantity surveyors. Smart and Sustainable Built Environment, 5(4), 325-339. https://doi.org/10.1108/SASBE-07-2016-0015

Yusuf, S. O., Adindu, C. C., \& Yisa, S. (2019). Expository Study on Sustainable Construction Practice in Project Delivery in Nigeria. In J. N. Mojekwu, L. Atepor, S. Sackey, L. Ogunsumi, \& E. Bamfo- Agyei (Eds.), Proceedings of the 8th Applied Research Conference in Africa (ARCA) (pp. 155 - 165). University of Ghana.

Zolfagharian, S., Nourbakhsh, M., Irizarry, J., Ressang, A., \& Gheisari, M. (2012). Environmental Impacts Assessment on Construction Sites. In H. Cai, A. Kandil, M. Hastak, \& P. S. Dunston (Eds.), Construction Research Congress, ASCE. ASCE. https://ascelibrary.org/doi/book/10.1061/9780784412329 